\title{
Morální normalita a sociální struktura současné společnosti
}

\author{
A Moral Normalcy and the Social Structure of Contemporary \\ Society
}

Martin Hájek

\begin{abstract}
In the debate over the nature of contemporary morality there are some who refer to the end of traditional morality and others to its aestheticisation, and still others who speak of its privatisation, its chaotic state or its lack of grounding and liquidity. Rarely, however, has the current situation been related to the social structure of advanced societies. In this article the author, inspired by both the historical analysis of the birth of purgatory and the concept of cultural allodoxy of the middle classes, develops a Durkheimian argument that the stratification of modern mass society has its analogy in the stratification of contemporary moral space. He argues that the binary categories of good and evil have been pushed into extreme positions and therefore they cover only a small part of the human action, while for the majority of normative evaluation, reference is made to an intermediate category of normalcy. The presented argument is an attempt to create a cultural sociology that would not partition cultural meanings and social-structural effects into two autonomous spheres of causality. It offers the perspective from which it is possible to present morality in a wider socio-cultural context, and which would take into account both the symbolic transformation (the loss of importance of transcendental authority) and social change (the mass society).
\end{abstract}

KEYWORDS morality, social structure, allodoxy, middle class, Bauman, normality

V debatách o povaze současné morálky se kromě obvyklého lamentování nad jejím úpadkem můžeme setkat i s opačným a relativně novým postojem. V jeho rámci je velká část veřejného a někdy i soukromého morálního posuzování považována za (pouhé) moralizování, které nahrazuje komplikovanou morální realitu jednoduchým černobílým viděním, ničícím ve svém důsledku samotný morální subjekt. Českým prríkladem této tendence může být Bělohradského koncept morálního kýče, který podle něj „,nahrazuje tíži morálního rozhodování, kamufluj[e] morální nejednoznačnost situací, v nichž bychom je měli aplikovat“ (Bělohradský 1999). V soudobé odborné literatuře se v tomto smyslu píše o konci tradiční morálky či post-morálce (Lipovetsky 1999, 2005), o její estetizaci (Welsh 1996; Lyotard 1993) nebo o její privatizaci, chaotičnosti a nezakotvenosti (Luckmann 1996; Bauman 1993; 1995). Jestliže z minulosti máme doklady moralizace každodennosti (např́klad posvěcení práce jako povolání [Weber 2009: 223-242]), tak v současnosti můžeme pozorovat trend

Sociálni studia. Katedra sociologie FSS MU, 4/2012. S. 67-85. ISSN 1214-813X. 
spíše opačný, ve kterém je každodenní chování zbavováno morální relevance, tj. jednoznačného vztahu k dobru nebo zlu. Tyto kategorie sice zůstávají platné, ale pouze pro krajní a relativně málo časté činy (např́iklad terorismus, nezištná pomoc apod.).

Jak už naznačuje výše zmíněný termín morální kýč, zasazování běžných životních situací do etického rámce opozice dobra a zla je považováno za pochybné moralizování vzdálené autentické morálce subjektu (Bauman 1995). Na druhé straně se legitimním ospravedlňujícím argumentem pro určité jednání stává odkaz na jeho častý a běžný výskyt, tedy odkaz na jeho normální charakter v durkheimovském smyslu (Durkheim 1926: 79-127). Vezměme jako prŕklad lhaní. I když se v minulosti jistě také lhalo a nad častým lhaním lamentovalo, tak samotná četnost lhaní neměla žádnou morální relevanci v tom smyslu, že by lhaní činila méně odsouzeníhodné. Posléze, však stále před označením lhaní za normální, mohla četnost lhaní vést $\mathrm{k}$ argumentu, že to není tak vážný prohřešek, když i ostatní lžou (viz Riesmanovi vnějškově řízení lidé; Riesman 1968). Váha argumentu tu spočívá už v empirické kvantitě aktu lhaní ve společnosti. Však v okamžiku, kdy se objeví argument, že „lhát je normální“, síla tvrzení, přestože odkazuje na faktický výskyt, je v normativní rovině, v proniknutí do specifického diskursu normality, ve kterém ani empirické ani morální argumenty nejsou rozhodující. Považme konkrétní příklad z tisku komentující jednání guvernéra americké centrální banky (FED):

Možná si [guvernér] myslí, že lhaní je normální. Že jeho prací je malovat věci na růžovo. Ví totiž, že psychologie hraje na trzích velmi důležitou roli a že když prohlásí, že všechno bude skvělé, stane se to i ve skutečnosti. Nikdy neřekne: „Tohle jsme nezvládli.“ Nelže tedy patrně proto, že by to byl špinavec, nýbrž s vědomím, jak je smýšlení trhů klíčové. Hraje o čas (Týden, 17. 8. 2009, s. 36).

Lhaní zde není prezentováno ani jako dobro ani jako zlo (není „špinavec“); lhaní je $\mathrm{v}$ dané situaci kontextuálně ospravedlnitelné odkazem na jeho normalitu, jakkoliv není jasné, zda je takové jednání časté (normální) nebo výjimečné. Konstatování, že něco je normální, má tak zvláštní schopnost vyvolat „zdání objektivní nutnosti“, jak by řekl Bourdieu (1979: 550). To neznamená, že proti tomu není možné argumentovat; konstatování normálnosti nás však znejistí v tom směru, že nevíme zdali argumentovat faktičností (lhát není normální/časté) nebo normativností (normální/správné je nelhat). Rozštěpení sil, které je důsledkem ambivalentního (fakticko-normativního) statusu pojmu ,normální“, tak umožňuje kolonizovat morální témata, protože do morálního diskursu vstupuje argument faktičnosti, který je ovšem vzápětí nahrazen normativností. Kupř́íkladu řeklo-li by se ještě v padesátých letech minulého století „braní drog je normální“, argument by zněl fakticky: braní drog je tak časté, že nebrat je výjimkou. Tehdy šlo argumentačně odrazit nárok na normalitu jen odkazem, že je fakticky nepravdivý, že drogy uživá jen malá část populace. Ovšem v okamžiku, kdy se ve společnosti nezávisle na faktickém stavu - ostatně jak objektivně změřit morální věc - uchytí mínění (at' už jakkoliv: skrze výzkum uživatelů drog, veřejného mínění nebo působením masových médií), že drogy berou i lidé ze slušných, „,normálních“ rodin, tak ten samý výrok (,brát drogy je normální“) je chápán jako normativní (brát drogy nelze považovat za morální prohřešek, poněvadž ,je to úplně normální“). Konsekventně, jediná možná normativně odporující odpověd' pak zní: „normální je nebrat!“‘Výsledkem je, že fenomén užívání 
drog - nehledě na jeho reálné rozšíření ve společnosti - se ocitl v normativním poli moralizované normality. Zpátky do morálního diskursu se může dostat opět jen tak, že se vyjme z diskursu normality; bez toho jakýkoliv morální apel zní jako pouhé moralizování.

$\mathrm{V}$ následujícím textu rozvinu $\mathrm{v}$ souvislosti $\mathrm{s}$ konceptem morální normality tři argumenty: konceptuální, genealogický a kulturní.

Na konceptuální úrovni budu argumentovat, že morálkou uvolněný prostor mezi kategoriemi dobra a zla je obsazen mnohem složitější a nejednoznačnější normativní strukturou, která proměňuje subjektivovanou morálku v kontextuálně založené normativní pole, jehož referenční rámec tvoří „,normalita“. Tuto strukturu označím jako morální normalitu. ${ }^{1}$ Pokusím se ukázat, že současná proměna morálky směrem k morální normalitě byla částečně popsána již přinejmenším dvěma autory: Z. Baumanem a J. Baudrillardem. První z nich se snaží definovat „normální“ jako to, „,o je dobré“, tj. eticky nefundovanou morálku, která by nebyla ukotvena v systému transcendencí jako tradiční morálka dobra a zla; druhý tvrdí, že nastupující morálka nemůže být morálkou subjektu a s ním spojeného patosu (Bělohradského morální kýč), ale měla by být „na straně objektu“. Domnívám se, že morální normalita dobře zapadá do těchto dvou linií uvažování, a tudíž by mohla být tím, co se Bauman i Baudrillard snaží postihnout, ale - podle mého názoru - nedokáží dobře uchopit. Dále bude mým cílem i negativní vymezení konceptu morální normality vưči dvěma pojmům, reprezentujícím paramorální struktury podobného ražení: zvykům a obyčejům (folkways) na jedné straně a na druhé straně adiaforizaci, tj. odstraňování morálního významu jednání ve prospěch racionálních, technických nebo procedurálních kritérií hodnocení.

Cílem genealogického argumentu bude vést pomocí příkladu zrození očistce (Le Goff 1981) analogii mezi pozdně středověkým sklonem vyhýbat se střetnutím způsobeným dualismem dobra a zla a podobným sklonem v době pozdně moderní. Prostřednictvím této analogie nedokazuji, že historie se opakuje, ale že proměna kultury i společnosti může být spojena s proměnou morálního prostoru jinak, než jen náhradou jednoho systému za druhý (přechod od jedné morálky $\mathrm{k}$ jiné), že změna může probíhat transformací stávajícího symbolického řádu, který se tak - dočasně či trvale - stává komplexnější.

Třetím cílem tohoto př́spěvku k sociologii morálky je pokus o sociologii, která by nebyla ani sociologií kultury, ve které má kultura funkci převodové skř́ně mezi sociální strukturou a subjektivní orientací lidí (Alexander 2003: 18), ale ani takovou kulturní sociologií, kde autonomie kultury jako systém významů generovaných v mezilidských interakcích znamená její totální odpojení od sociální struktury. V části věnované propojení mezilehlé sociální vrstvy a morální normality předestřu způsob, jakým může být sociální struktura aktéry překládána do struktury morálního univerza. Tento překlad není mechanický, nýbrž hermeneutický. Jak jsem ukázal ve své dřívější práci (Hájek 2001), sociální struktura je interpretována vždy z určité pozice a její reprezentace vypovídá z velké části o kategoriích, které jsou v této pozici dostupné. „Překlad“ sociální struktury je proto koordinovaná činnost, která probíhá na mnoha úrovních a zahrnuje jak kooperační, tak i konfliktní procesy. V tomto textu

Jsem si vědom nejasnosti složeného konceptu „morální normalita“. V angličtině existuje „,normalcy“, což by bylo možné s jistou licencí přeložit jako „normálka“. V češtině se ovšem slovo „normálka“ používá jako hovorový výraz pro normální a jako odborný termín se tedy nehodí. 
budu konkrétně rozebírat, jak příslušníci střední (mezilehlé) vrstvy překládají svou sdílenou zkušenost života do vlastního étosu a jak tento étos společně $\mathrm{s}$ tím, jak se rozšiřovala střední vrstva $\mathrm{v}$ druhé polovině minulého století, mohl vést na konci století $\mathrm{k}$ širokému rozevření prostoru mezi morálními kategoriemi a vytvořit tak místo pro morální normalitu.

\section{Baumanova post-moderní morálka bez základů}

Zygmunt Bauman ve své studii o postmoderní morálce tvrdí, že dnes jsme si vědomi toho, že morálka nemá ani důvod, ani prŕčinu a že nutnost býti mravným, stejně jako smysl toho, co je morální, se nedá logicky zdůvodnit ani názorně demonstrovat. V takovéto situaci ,jen jednou věcí si můžeme být jistí: ve společnosti, která otevřeně přiznala, že jí chybí základy i cíl, a v níž pouze vratká lávka přemost'uje propast, kde měly být její základy, může existovat jakákoliv morálka, může to ale být pouze morálka eticky nefundovaná. Musí tedy být i nekontrolovaná a nepředvídatelná“ (Bauman 1995: 127). Eticky nefundovaná morálka je taková, ve které morální jednání nelze ospravedlnit odkazem na nějaký systém transcendencí (boha nebo rozumu). Morální jednání nemůže proto čerpat svou mravnost z vnějšího zdroje, ale jen z vưle aktéra. Morálka musí být autonomní a autonomie musí být vázaná výhradně na individuální osobu, na subjekt.

Ačkoliv postmoderní morálka autonomních subjektů je podle Baumana „,nekontrolovatelná a nepředvídatelná. Tvoří se sama, může proto zrušit to, co vytvořila, a zbudovat to ve zcela jiné podobě“ (Bauman 1995: 127), přece jen nejde o absolutní „nefundovanost“: základním kamenem veškeré morálky je dle něj bytí pro druhé. ${ }^{2}$ To zní konsekventně s úvahami o netranscendentní morálce: jestliže na světě nejsme pro Boha ani pro Rozum, tak jen pro druhé lidi - anebo sami pro sebe. Sklonu k individualismu a potažmo egoismu se Bauman snaží zabránit poukazem na možné strukturní zakotvení morálky - sociální stát. Stát sdíleného blahobytu institucionalizuje morální odpovědnost jednotlivců tím, že konstituuje sdílenost osudu. Snaha poprrít tuto sdílenost osudu je podle Baumana současně snahou zbavit se morální odpovědnosti vůči druhým (Bauman 1996).

V souvislosti s konceptem morální normality je relevantní Baumanova charakteristika morálky „obyčejných lidí“. Tvrdí, že „lidé se nestávají méně mravnými, než byli dřive. Jsou dnes ,nemorální pouze v tom smyslu, v němž by se ukázali jako nemorální i v době moderní [...], kdyby se na jejich reálnou životní praxi vztáhla eticko-filosofická kritéria“ (Bauman 1995: 159). Podle něj lidé nejsou o nic méně morální, než byli dřive, pouze jejich nemravnost není s takovou pečlivostí zakrývána. Nebo jinak: reálná životní praxe se vzhledem $\mathrm{k}$,,morálce“ nezměnila, protože ani v době moderní nehrály morální principy a povinnosti určující roli.

Pozastavme se nakonec ještě u Baumanova postřehu: „Normální život - pokud to má být dobrý život - by měl být neustálými prázdninami“ (Bauman 1996: 55). I když nemusíme souhlasit s tím, že dobrý život by měl být jako neustálé prázdniny, všimněme si formulace „,normální život, pokud to má být dobrý život“. Podle mého názoru se zde Baumanovi hledajícímu

2 Bauman tuto pozici rozpracoval ve své knize The Postmodern Ethics, kde vycházel z morální filosofie E. Lévinase (Bauman 1993). 
formu postmoderní morálky podařilo bezděky zachytit klíčový aspekt té současné morálky: soužití morálky s normalitou. Bauman netvrdí, že normální život jako permanentní prázdniny je pro postmoderní obyvatele také morální život, ale pouze „dobrý“ život; současně to není ani nemorální život. Pro současného člověka opozice „morální-nemorálni““ nepokrývá celé morální spektrum, pouze jeho okraje. To, co ho zajímá především, je ono normální, které je dobré, nacházející se v mezilehlém prostoru morálky. Baumanův př́klad nám ukazuje, že hledání nezakotvené morálky současnosti nás dovede k morálce-nemorálce „obyčejných lidi“ a současně k morálce jako tomu „normálnímu, co je dobré“.

\section{Baudrillardova morálka bez subjektu}

Co je to za morálku-nemorálku, která je eticky nefundovaná, ale o to více autentická? Co je v jejím jádru, ale zároveň mimo dobro a zlo? Jean Baudrillard (1995) podle mého názoru přináší lepší řešení než Bauman tím, že morálku rozděluje na dvě úrovně: na jedné úrovni morálka zůstává založená na morálním subjektu, který se skrze ní stále vztahuje k nějaké transcendenci, zatímco na jiné úrovni - ta zajímá Baudrillarda především - je subjektivita aktéra nepodstatná a „otázku morálky nelze ani položit“. Přesto i tato úroveň či sféra nějakým způsobem k morálce patří, i když negativně; je to ta část morálky, kde morálka, jak ji známe, neexistuje.

Baudrillard tvrdí:

Musíme mluvit o jiné úrovni, kde již neexistuje morálka, kde věci jsou analyzovány takovým způsobem, který jde až za morálku. A to nejen v Nietzscheho smyslu - což by znamenalo, stejně jako u Bataillea, představu „překonání“ nebo transgresi hodnot, přehodnocení hodnot atd. -, ale, jsme-li v prostoru objektu (prostoru, který je na té druhé straně), tak refrakce tohoto prostoru už není vůbec ta samá a zde otázku morálky nelze ani položit. (Baudrillard 1995: 88)

Konkrétně tento problém dokládá na fungování mediálního zpravodajství. Nelze se podle něj žádným způsobem spolehnout na nějakou etiku zpravodajství a podřizení či nepodřízení se jejím imperativům, protože mezi zpravodajskými médii a transcendencí morálky neexistuje žádný smysluplný vztah: zpravodajství a média fungují na bázi styčnosti (kontiguity), kapilarity, na bázi jakési totální metonymie; není zde možnost nějaké morální metafory, morální transcendence apod. Hledat východisko v morálce subjektu by v této situaci bylo nikam nevedoucí a špatné řešení.

Nicméně k vyřešení problému současné morálky nestačí uvědomění si toho, kde není; je třeba pozitivně zjistit, jaká je její povaha. Baudrillard se v tomto směru vyjadřuje bohužel dosti tajuplně. Doporučuje věnovat pozornost formám (spíše než obsahům), které jsou podle něj nezničitelné. Formami myslí svádění, výzvy, reverzibilitu.

Reverzibilita je zejména formou. A nevede $\mathrm{v}$ žádném př́padě $\mathrm{k}$ morálnímu principu jednání; je to forma, a co zde máme, je hra. [...] Dodržování pravidel hry není morálka, ale jednoduše přizpůsobení se hře samotné. Nejde o to, zda přijímám nebo odmítám pravidlo. Hraji a pokud hraji, existuje zde imanentní pravidlo. Pravidlo, které není definováno jako něco někde jinde, jako něco hře 
transcendentní. Je hrou samotnou: způsobem nebo hrou světa. A pokud jsem v této hře - na úrovni zdání apod. -, pak v ní neexistují žádné zákony nebo morálka. To však neznamená, že to je nemorální v d’ábelském, „špatném“ významu slova. (Baudrillard 1995: 89)

Když je nucen s něčím srovnat svou představu morálky, poukazuje na zbavování se, pravidlo stoiků, které Baudrillard transformuje do jediné ctnosti - nepřidávat světu patos. Dovolím si ještě naposledy autora př́mo citovat:

Jediným způsobem [jak dosáhnout morálky] by bylo vyčistit prostor okolo objektu jako býval, a jednat tak, že se svět rozzáří ve vší své indiferenci, ve své imoralitě, ačkoliv ne v negativním smyslu - možná amoralitě je lepší slovo -, takže subjekt sám by se mohl naladit vůči světu, harmonizovat se světem v jakési symbolické směně indiference. (Baudrillard 1995: 90)

Baudrillard jen těžko hledá pro tuto ne-morálku označení; proto tak obezřetný popis, aby nedošlo k omylu. Zdá se, že ne-morálku neřídí Zákon, nýbrž pravidlo. Zákon - a Baudrillard tím myslí i morálku transcendence - je vždy sacré, vyvolává v lidech ,pod Zákonem“ touhu po jeho překročení, po transgresi či subverzi; na druhé straně pravidlo - morálka indiference $-\mathrm{s}$ sebou patos posvátného nenese, jeho překročení hru neohrozí, je to její součást (Baudrillard 1996). Ne-morálka nemá obsah, nemá smysl, který by bylo možné interpretovat, protože je samo-žrejmá, evidentní, je to forma. Dokonce tak uzavřená, autoreferenční, že se zdá být iluzí; však nikoliv v nemorálním smyslu, není to „d’ábelská“ iluze - podobně jako není nemorální iluze mediálního zpravodajství.

Subjekt, na jedné úrovni náležící Zákonu a morální transcendenci, ve které je svět jen metaforou, se v druhé úrovni může dotknout světa, bude-li s ním „rezonovat“ s dostatečnou indiferencí. Tato druhá, ne-morální úroveň, o které Baudrillard mluví, je podle mne morálně orientovaná normalita.

\section{Co je to morální normalita?}

V předchozích odstavcích jsem se pokusil prostřednictvím kritické analýzy dvou pokusů o vymezení současné morálky ukázat, že se objevuje prostor pro nějakou jinou morálku „nepatetickou,“" „reverzibilní“ morálku „normálního, co je dobré“. V následujícím textu tuto zvláštní paramorálku popíši.

Morální normalitu je možné v prvním přiblížení připodobnit $\mathrm{k}$ instituci sociální regulace postihující běžné chování, na které se zpravidla nevztahují legální ani morální zákazy, nicméně tato instituce zajištuje vzájemnou behaviorální i kognitivní důvěru a předvídatelnost (Misztal 2001). V žádném př́ípadě netvrdím, že normalita chování je něco nového, ba přímo postmoderního; naopak normalita se ustavuje v každé společnosti (Durkheim 1895: 59-93). Co však charakterizuje vyspělé společnosti naší doby, je zvláštní moralizace normality. Ve společnosti, kde platí morální pravidla, je dojem určité normality di̊sledkem působení morálky: je-li heterosexualita prožívána jako morální, je nenormálnost homosexuality jen insignifikantním statistickým odleskem její nemorálnosti. Je-li krádež nemorální, její častý výskyt - běžnost, normalita - nic neubírá na její morální zapovězenosti. Morálka totiž není 
chápána jako záležitost faktického prokazování, nýbrž jako idealita s pouze jednosměrným působením. Proto morálka vyžaduje oporu v transcendentní moci, která zajišt’uje její „zpětnou vazbu“. Jinak řečeno, mezi morálním dobrem a nemorálním zlem není žádný prostor pro morálně neukotvenou a obhajitelnou morální normalitu bez transcendence.

Na druhé straně, dnes se můžeme zcela běžně setkat s tím, že určité chování je odsuzováno nebo naopak obhajováno jen proto, že je „(ne)normální“, protože nelze nalézt žádnou metafyzickou (transcendentní) instituci, která by poskytla hodnocení náležitou morální oporu. ${ }^{3}$ Ovšem je nutno mít neustále na paměti, že samotné odsouzení něčeho jako nenormálního jednoznačně neznamená odsouzení z nemorálnosti, nýbrž zpravidla jen vnesení tématu do morálního diskursu. V samotném prohlášení, že homo/heterosexualita je (ne)normální, není nic konstitutivně moralistního - pouze je tak vymezen diskurs, ve kterém se téma má pojednávat (Foucault 1994). Řekne-li se: ${ }^{4}$ „heterosexualita či homosexualita (lhaní-pravdomluvnost; krádež-respekt k majetku; nepořádek-pořádek) je normální", znamená to pro ostatní, že řečník nemá zájem věc tematizovat jako morální záležitost. Na to poukazuje i Luckmannem (1996) zjištěná „nepřímost“ moralizování. Teprve spolu s označením situace či skutku jako nenormálních se otevírá prostor pro morální posouzení. Považování něčeho za normálni je jako krunýr̆, který chrání posuzovanou záležitost před morálním hodnocením. Teprve prolomení této ochranné slupky otevírá pole pro morální argumentaci.

Morální normalita není jen způsob diskursivní argumentace, jak by se mohlo z výše uvedeného zdát. Podobně jako morálka, morální normalita především usměrňuje způsoby chování a myšlení a dává návody, jak porozumět chování ostatních; tzn. „,normálně“ se chováme tehdy, když chceme vyjádřit své členství v dané skupině či sociální kategorii, tzn. nechceme-li, aby naše členství ve skupině, respektive kategorii, bylo zpochybňováno. Jinak řečeno, chováme se podle zvyklostí dané skupiny. Nicméně „zvyklostem“ rozumíme trochu jinak, než bývalo zvykem: zvyk byl odvozen z nějaké události transcendentního významu nebo byl spojen s tradicí, tj. opakováním historického rozměru. Zvyklosti morální normality nespočívají na ničem jiném než na konvenci - a jejich porušení neznamená nic jiného, než poukaz na speciální motiv nebo povahu narušitele, otevřený morálnímu posouzení. Morální normalitu můžeme chápat ve smyslu Baudrillardova pravidla - její porušení není transgresí, která by nás osvobodila, nýbrž je jedním ze způsobů hry. Skutečnost, že má blízko k ,pouhé“ konvenci, nijak nesnižuje její utlačivost vůči členům společnosti. Dokonce se lze oprávněně domnívat, že je přísnější než současná roztř́šstěná a nezakotvená morálka. Sice ne v patosu odsouzení, patos morální normalitě nepř́isluší, její prrísnost spočivá v předpokládané objektivitě a nelítostnosti. Např́iklad vlastní-li někdo něčeho více nebo méně, než je hranice „normálního“, vystavuje se, bez ohledu na jeho subjektivní postoj, morálnímu posouzení: je to dobře, nebo špatně? Někdo rozdá veškerý majetek a jde pomáhat do nemocnice - udělal nenormální čin a je třeba posoudit, zdali to bylo od něj dobré nebo špatné. V prvé řadě se

\footnotetext{
3 Např́iklad: „Nepovažuji schůzku s šéfem ÚOHS Martinem Pecinou, kterou natočila ABL a odevzdala ČT, za nic nenormálního“ (Respekt, 24. 10. 2011, s. 7). O pojmu normality v denním tisku pojednává napríklad Hájek (2004).

4 Pochopitelně mám zde na mysli: řekne-li se bez ironie...
} 
nezkoumá morálnost daného činu nebo situace, nýbrž normálnost; jakmile je rozhodnuto o nenormálnosti, přichází ambivalentní stanovení dobra a zla.

Principem působení morální normality, na rozdíl od morálky, není reprezentace. Morální normalita nereprezentuje žádnou autoritu, včetně pomyslné autority mas. Proto ji nelze vykládat ani pro ni nelze vymyslet etiku. Kdybychom hledali její princip, snad by to byla „iterace“ (opakované posuzování). Charakteristická pro morální normalitu a pro to, co jí odlišuje od morálky, je skutečnost, že není kategorická, nýbrž pozvolná. V morálce se vždy rozhoduje kategoricky - dobro, nebo zlo. Nelze krást, lhát nebo zabíjet napůl. Euthanasie je, nebo neni morální, př́ípadně je upřesněno, za jakých okolností. Na druhé straně morální normalita tuto kategoričnost nevyžaduje, stupňovitost je jejím charakteristickým rysem: vůbec nelhat nemusí být normální, zalhat výjimečně už je více normální, lhát občas už je zcela normální, lhát soustavně už moc normální není atd. V tomto rysu se podobá Foucaultově disciplinární normalizaci, známkování a trestání odnětím svobody s př̌esnou lineární soustavou trestů (Foucault 2000).

Baudrillard uvažoval o morálce nezaložené na subjektu, o morálce indiference. Logicky, v morální normalitě není místo pro svědomí, a tím pádem ani pro subjekt. Člověk nemůže mít výčitky svědomí, že se nezachoval normálně (např́klad v dané situaci nelhal respektive lhal); může pouze litovat, že promarnil určitou př́iležitost. Morální normalita nevyžaduje subjektivitu, není otázkou motivace či záměru. Je-li něco „úplně normální“, tak i když je subjektivita samozřejmě v normativním soudu obsažena, kam situovat subjekt? Pouze mimo, jako pozorovatele; normální se nevztahuje k subjektu, ale k situaci. Jestliže považuji nějaký skutek (lhaní) za normální, nekladu si tím jako subjekt a priori žádnou povinnost, pouze vytyčuji kontext, v kterém se skutek má posuzovat. Naopak prohlásím-li o lhaní, že je nemorální, tak tím pádem říkám, že v prvé řadě pro mne, jako pro rozhodující se subjekt, to není přijatelné jednání. Také se zdá, že s čím větším odstupem, s čím větší indiferencí je k morální normalitě přistupováno, tím větší má normativní efekt.

Taková „objektivní sdílenost“, kterou označení „,normální“ vyvolává, nepotřebuje ke své přesvědčivosti žádný patos; i když existují speciální případy patetické normality, chtějí tak spíše podtrhnout nenormalitu: např́klad když fotbalová nebo jiná „hvězda“ prohlásí, že je „úplně normální kluk/holka“.

\section{Co normální moralita není}

Normativní instituce, podobné té, kterou zde popisuji, ale v určitých a důležitých rysech rozdílné, byly v sociologii už dříve konceptualizovány. Protože tyto konceptualizace nejsou pro naše pojetí natolik inspirující jako Baumanovy a Baudrillardovy úvahy o postmoderní morálce, zmíním je jen stručně. Nejstarším podobným konceptem jsou zvyky, folkways. Sumner považuje „folkways“ za ustálené způsoby myšlení a jednání, které se osvědčily; jejich vznik je neuvědomělý, protože jsou výsledkem působení přírodních sil; teprve tehdy, když se k nim připojí etické významy, stávají se mravy, mores (Chalupný 1948: 356-357). Na rozdíl od folkways, které Sumner pravděpodobně chápal jako empiricky normální způsoby jednání, morální normalita není spojená s vývojem společnosti jako celku, ani s tím, co se osvědčilo; především však morální normalita není pozitivní vymezení životních způsobů, 
neurčuje, jak se má jednat, např́íklad pozdravit, nýbrž udává limity, ve kterých pozdravení nevyvolává nutnost morálního posouzení.

V souvislosti s folkways je relevantní myšlenka G. Böhma, který tvrdí, že současná společnost trpí ztrátou etického života a že jediné, co z morálního rozměru zůstalo, jsou „Zvyklosti“ (customary) (Böhme 2000: 5). Pro nás je zajímavé, že jeho pojetí zvyklostí se blíží zde rozvíjenému pojetí morální normality. Tvrdí např́klad, že „,všechny zvyklosti jsou v principu podezřelé z toho, že jsou nemorální" (tamtéž: 7). Za pozornost stojí i myšlenka, že zvyklosti se rozhodující měrou podílejí na faktické stabilitě společnosti. Lidé totiž podle něj neporušují zákonné normy proto, že je jejich porušení trestné, ,ale proto, že to není patřičné či vhodné. Činy: fyzické násilí, přepadení, znásilnění, vražda, vandalismus. Samozřejmě se tyto činy stávají, ale jsou stíhatelné, právě protože netvoří zvyklosti. Jestliže se tak stane, tak právo a policie jsou bezmocné“ (tamtéž: 8). Ačkoliv i ,zvyklosti““ a morální normalita mají některé společné rysy (například jsou morálně podezřelé), morální normalitu nelze považovat za normativní ekvivalent morálky s jejím rozlišením dobra a zla, ani jako zdroj loajality vůči zákonům.

Při přehledu toho, co se morální normalitě podobá, se nelze vyhnout konceptu adiaforizace (Bauman 1991, 1993, 2006), kterým se Bauman snažil postihnout proces vedoucí k podobným efektům jako zde popisovaná morální normalita, tzn. k rozšiřování prostoru mimo morální posouzení. Jeho podstatou je zbavení určitého jednání morálního významu, učinění ho morálně irelevantním a poměřitelným pouze racionálními, technickými nebo procedurálními kritérii. Exemplárním př́ípadem moderní adiaforizace byl holokaust, kdy hromadné morálně nepř́ípustné jednání bylo převedeno na technicko-správní otázku. Ačkoli na první pohled se zdá, že morální normalita a adiaforizace odkazují k témuž jevu, není tomu tak; naopak, ve velice podstatných aspektech se jedná o protiklady. Zaprvé, morální normalita nesouvisí podstatným způsobem s moderními organizacemi ani s racionálně účelovým charakterem jednání. Zadruhé, i když označení nějakého jednání jako normálního ho sice vyjímá ze sféry morálního posouzení, respektive morální soud mění v pouhé moralizování, stále ponechává toto jednání v normativním poli; je to způsob, jak ho v něm udržet, nikoli ho z něj vyloučit. Zatřetí, morální normalita je na rozdíl od adiaforizace reverzibilní, je schopná nějaké jednání učinit morálně problematické tím, že „není normální“. Naproti tomu adiaforizace je pro Baumana jednosměrný proces, který nám neslouží jako náhražka oslabené morálky, ale který je namíren přímo proti ní. Posuzování normalitou je však způsob, jak činit normativní soudy v situaci, kdy nefundovaná a patetická (kýčovitá) morálka neplní svou funkci.

Rozdíly procesů adiaforizace a morální normality ještě neznamenají, že spolu nemohou koexistovat. Jsou známy situace, kdy adiaforizované jednání je označeno za nenormální $\mathrm{s}$ implicitně vyžadovaným morálním posouzením. Nejlépe je to viditelné na př́ípadech formálně právně nepostižitelného, ale morálně problematického jednání. Argumentace nenormálností, nikoli nemorálností, se tak stává účinnou obranou proti adiaforizačním tendencím. $\mathrm{Na}$ druhé straně existují prŕípady, kde argument (ne)normality jde v ruku v ruce s neutralizací morální dimenze jednání, zejména při popírání individuální odpovědnosti a zbavování práva vlastní volby. 


\section{„Zrození“ morální normality}

Když byly takto vylíčeny základní rysy morální normality jako morální instituce, pokusím se nabídnout i hypotézu jejího zrodu. Napřed je však třeba vysvětlit, jak je zde chápán pojem „zrod“ a k čemu má tato genealogická exkurze sloužit. Zrod je používán ve Foucaultově smyslu historických náhod, souvislostí a přerodů, které lze při sledování určitého jevu nebo instituce v čase vystopovat (Foucault 1994: 75-94); nejde proto o jejich historický vývoj od primitivního k vyvinutému, ale o proměny. Cílem je pak ukázat na vzájemnou souvislost sociální struktury a kultury, která je zde chápána především jako určitá sociálně-kategorizační imaginace. Tento vztah není jednosměrný; sociální struktura má potenciál proměny a diferenciace, ale kultura, respektive sociální aktéři, přisuzují smysl jen těm diferencím, které považují ze svého hlediska za relevantní. Jaký význam bude tomu či onomu prvku přisouzen, už není určeno sociální strukturou, ale způsobem jejího výkladu a symbolickými zdroji, které jsou aktuálně k dispozici.

Inspirace k hypotéze zrodu morální normality přichází od historika Jaquese Le Goffa. Ten ve své historické studii Zrození očistce (Le Goff 1981) popisuje, jak sice válkami a ideologiemi unavená, však hospodářský vzmach zažívající francouzská společnost konce 12 . století nechtěla dále snášet extrémní volbu mezi nebem a peklem, dobrem a zlem. Od konce čtvrtého do poloviny dvanáctého století žila společnost v představě ideální obce Boží. Z tehdejšího pohledu bylo důležité, aby se pozemská obec navzdory svým nedostatkům nezhroutila na d'áblovu stranu, na stranu zla. Však od konce jedenáctého do poloviny třináctého století už nepostačovala jednoduchá černobílá perspektiva (Le Goff 1981: 283). Bylo stále zřejmější, že jen málokdo, zvláště z dynamicky expandující skupiny ekonomicky aktivních měštanů, byl natolik čistý, aby po své smrti mohl prímo do nebe, a jen málokdo tak hříšný, aby musel do pekla. Le Goff konstatuje, že v raném středověku, kdy konec světa byl ve vědomí lidí stále nablízku, nebyla možná jiná morální volba než mezi nebem a peklem a cokoliv mezi tím by bylo bývalo nepřiměřeným přepychem (Le Goff 1981: 25). Ovšem v desetiletích po uplynutí milénia bez božího príichodu či dokonce bez jakéhokoliv znamení se církevní myslitelé nemohli smíŕit s prostou opozicí mezi rájem a peklem, a když k tomu byly vhodné podmínky, bylo objeveno třetí zásvětní místo - očistec. Očistec v těchto představách byl především místem pokání a vnitřní konverze, spíše než místem vnějšího jednání.

Jedním z prvních kroků, kterými se rozvíjející společnost na přelomu tisíciletí chtěla vymanit z prrísné morální duality, bylo znovuobjevení Augustinovy klasifikace křest’anů do čtyř skupin: zcela špatní, středně špatní, středně dobří a zcela dobří.

[Očistec] totiž povstává z obecného sklonu vyhýbat se střetnutím způsobeným redukujícím dualismem; mezi póly dobra a zla, nadřazeného a podřazeného, rozlišuje průměrné, střední a mezi hříšníky ne úplně dobré a ne úplně zlé - tj. augustinské rozlišení -, kteří nejsou bezprostředně zasvěcení ani ráji ani peklu. (Le Goff 1986: 82)

Augustinovo rozdělení bylo upraveno na trojné sloučením dvou středních kategorií do jedné prostřední - tj. kategorie lidí prostředních (mediocres), nacházejících se v morálním prostoru mezi čistotou světců a proviněním zločinců. Současně se ustanovila nová kategorie 
„malých“ (minuta), „lehkých“ (levia), „každodenních“ (quotidiana) hříchů, ze kterých se mohl člověk očistit pokáním v očistci.

Očistec vznikl jako místo mezilehlé. Jak časově - mezi smrtí a posledním soudem, tak prostorově - mezi rájem a peklem. Nejdříve se musel odpoutat od pekla, jehož nejvyšší vrstvou zprvu byl, aby se nasměroval k nebi, jež bylo jeho jediným východem. Mezilehlost nemusí být žádným způsobem symetrická. To podstatné je v řádu logiky. Aby mohl očistec vzniknout, je třeba mít pojem mezilehlosti. Logickou strukturou je pojem mezilehlosti svázán s hlubokými změnami sociálních a mentálních realit středověku: nenechat se už ovládat protiklady mocných a ubohých atd., nýbrž hledat nějakou střední kategorii nebo třetí rád. Podle Le Goffa nelze prrímo a kauzálně spojovat zrod očistce se zrodem třetího stavu, měšt'anstva a potažmo střední třídy; jak očistec, tak vrstva měšt'anů jsou dva spojité aspekty velké přeměny feudálního křest’anství.

\section{Propojení mezilehlé vrstvy a morální normality}

Bylo by nesporně zajímavé foucaultovsky hledat dvojí ekonomii morální normality a morálky; srovnání s ekonomií očistce se k tomu přímo nabízí. Morální normalita jako „užitečná“, hospodárná mravnost nevybíjející se v dramatickém a stravujícím střetu dobra a zla, nýbrž účinně absorbující a transformující většinu morálních otázek. Přesto, nebo právě proto, lidé, kteří pocitují dobro a zlo jako vzdálené a abstraktní, jsou ochotní obětovat normalitě většinu své životní energie. Abychom však mohli klást podobné foucaultovské otázky, je třeba si nejprve ujasnit rozvržení situace, prozkoumat topologii sociálního prostoru, odkrýt souvislosti mezi normativní a sociální strukturou. Nepůjde nám proto o pátrání po proměnách moci; více nás bude zajímat logika struktury, terén bojiště, kulisy, ve kterých se moc, tak bravurně Foucaultem odhalená, uskutečňuje.

Př́iklad zrodu očistce nabízí způsob, jak naložit s problémem morální normality. Nenacházíme se v posledním půlstoletí opět (a zatím) v situaci, kdy existuje rozsáhlá vrstva lidí, kteří svůj status vnímají jako mezilehlý, vymezený relativně nepočetnými, o to však viditelnějšími, krajními kategoriemi těch druhých, vůči nim „nahoře“ nebo „dole“ (Hájek 2001)? Nesouvisí toto seberozumění s prakticky paralelním prosazením se pojmu normality jako něčeho přirozeného, ,normálního“? A konečně, prolíná se étos mezilehlé vrstvy lidí s tím, co bylo výše označeno jako morální normalita? I když odpovědi na tyto otázky nelze vyslovit určitě a jednoznačně, pokusím se vytvořit alespoň vodítko k jejich hledání.

$\mathrm{V}$ hypotéze, která zde bude rozvinuta, půjde o to, ukázat společné charakteristiky střední třídy ${ }^{5}$ a morální normality. „Normální“ se vyznačuje vnitřní neurčeností, lze jej vymezit pouze ve vztahu k ne-normálnímu; navíc, normální lze vždy zpochybnit otázkou „co je

Střední tř́ídou se zde rozumí reálná historická entita, tzn. buržoazie, později rozdělená na malou a velkou. Protože ve středu, v mezilehlé pozici, byla zpočátku buržoazie spíše „větší“, ta, která později splynula s „vyššími třídami“, bude se historické líčení soustředit především na ni. Postupem doby se do mezilehlé pozice posunovala více buržoazie „menšsi“, maloměštáci, nepatřící ani k elitě ani k nižším třídám, a proto se analýza současné situace (Bourdieu) zaměří na ni. Tím bude, podle mého názoru, $\mathrm{v}$ diachronii souvisle sledován étos mezilehlosti. 
vlastně normální?“ Střední tř́da, alespoň jak je líčena v dílech historiků a empirických sociologů, sdílela s normalitou tyto rysy v takové míře, že normalitu lze považovat za její generalizovaný étos, který následně umožnil vznik morální normality jako mezilehlého prostoru morálního univerza.

\section{Allodoxie}

Nejvýznamnější rys, který sdílí normalita a střední třída a který vychází z logiky postavení v symbolickém, respektive sociálním prostoru, je bezesporu problematičnost jejich určení.

Pro nikoho, kdo zkoušel to slovo definovat nebo nalézt jeho sociální referent, nebude žádným překvapením, že v osmnáctém století „buržoa“ byl krajně ošemetný termín: znamenal, že jste něčím nebyl (gentlemanem, dámou, dělníkem, dvořanem), znamenal, že jste se nedokázal chovat určitým způsobem. (Maza 1997: 211)

Zkusme tuto charakteristiku termínu „buržoa“, označujícího člověka v mezilehlém postavení, přisoudit termínu „normální“: je to rovněž ošemetný termín znamenající nebýt někým (bláznem, géniem, zločincem, světcem), prostě být tím, kdo se nechová určitým normálním - způsobem. Podobně můžeme aplikovat tuto záměnu na pojem střední třídy, která je

nejumělejší z dobře známých sociálních seskupení. Na rozdíl od aristokracií, jejichž existence obvykle spočívá na kombinaci právní výlučnosti a př́buzenských vztahů, a venkovských i městských dělnických tř́d, které spojují společné formy a předmět práce, střední třída existuje z definice pouze ve vztahu k jiným sociálním skupinám. (Maza 1997: 201)

P. Bourdieu spatřuje důsledek této neurčitosti v kulturni allodoxii střední třídy; již od svých počátků, kdy vznikala v úzkém prostoru mezi aristokracií a prostým lidem, byli její př́slušníci spíše těmi z lidu, kterým byla aristokracie referenční skupinou; byli proto

nejistí ve svých zařazeních a rozpolcení mezi vkusem své náklonnosti a vkusem své vůle, [...] jsou odsouzeni k nesourodým volbám [...]: a to jak ve svých hudebních či výtvarných preferencích, tak svých volbách každodenních. (Bourdieu 1979: 376)

Příslušníci střední třídy usilovali o to, jakýmkoliv způsobem se vymanit z riskantního mezilehlého postavení, a jediný způsob, který se nabízel, pokud nechtěli rezignovat na sociální vzestup, bylo přijetí norem své referenční skupiny, vyšších vrstev (aristokracie). Ovšem protože tyto elitní normy a způsoby jim nejsou biograficky a v jistém smyslu ani historicky vlastní, jejich osvojování bylo stále provázeno úzkostí, zdali nejsou takříkajíc špatnými učedníky.

Tato čistá, však prázdná dobrá vůle, bez značek nebo principů nezbytných $\mathrm{k}$ jejímu použití, bez znalostí jakému předmětu se oddat, činí z měštáka obět' kulturni allodoxie, tzn. všech chyb iden- 
tifikace a všech forem falešného poznání, kde se prozrazuje rozdíl mezi poznáním a uznáním. Allodoxie, heterodoxie žitá v iluzi ortodoxie, která vytváří tuto nediferencovanou uctivost, mísící chtivost s úzkostí, vede k považování operety za „,velkou hudbu“ (grande musique), popularizace za vědu, napodobeniny za originál... (Bourdieu 1979: 370)

Srovnáme-li tuto situaci s tím, co jsme zjistili o vnímání normálního, nabízí se myšlenka, že normální se stalo jakýmsi únikem nebo přesněji opevněním se, zabarikádováním se před „chybami identifikace“. V jádru normality jako normativní orientace je také obava před „chybami identifikace“ dobra a zla, nejistota vzhledem k morální autonomii. Když dospělý vysvětluje dítěti, co je „normálni'“ a co ne, vyhýbá se tak dnes problematickému terénu morálních voleb a pochybností. „Vzhledem k okolnostem je normální, že takto jednal,“ uvedené jako př́klad u hesla Normální (Normal, -e) ve slovníku Larousse (Grand dict. enc. Larousse, 1984), svědčí o schopnostech normálního diskvalifikovat nebo alespoň oddálit morální posouzení. Normalita má svůj analogon v kultuře střední třídy, která sebe sama chápe v prvé řadě jako protiklad lidovosti, hrubosti (Bourdieu 1979: 370). Také normalita je v normativním kontextu pojímána jako ne-zlo, jako hodnota jednání, které s největší pravděpodobností (posílenou dobře známými historickými výjimkami) není zlem, a proto může v určitých případech dokonce aspirovat na ztotožnění s dobrem (normální jako správné). Proto je kritika morální normality z pozice morálky podobná té vztahující se na kulturu střední tř́dy.

To, co dělá prostřední kulturu (culture moyenne), je vztah maloměštáka ke kultuře, chyba předmětu, mýlka, víra na špatném místě, allodoxie. A je nutné bránit se chápání tohoto subjektivně i objektivně nešt'astného vztahu substanciálním způsobem [...]: to, co vytváří vztah maloměštáka ke kultuře a jeho schopnost proměnit $\mathrm{v}$ prostřední kulturu vše, čeho se dotkne, není, lze-li to tak ř́ci, jeho „přirozenost“, nýbrž samotná pozice maloměštáka v sociálním prostoru. (Bourdieu 1979: 377)

Podobným způsobem se nelze spoléhat na normalitu:

Ti, kdo hranici normality a nenormality nepřekračují, kdo přistoupili na její vymezení, ti, kdo dodržují dohodu, budou - jak by se mohlo na první pohled zdát, v životě úspěšnější než ti druzí. Nebudou na sebe přivolávat posměch, pohoršení, trest. Ovšem, pohlédneme-li na takzvané úspěšné lidi, zjišt'ujeme, že právě tito lidé byli dlouhou dobu považováni - v drtivé většině - za nenormální. (Martin 1998: 15)

Dilema normality má svůj kořen v dilematu střední vrstvy; tedy ve strachu, že v momentu, kdy se začneme spoléhat jen výhradně na ni, nás pravděpodobně zradí.

\section{Vzdělání, vědění a mínění}

Ve Velké Británii byla [v 19. století] většina internátních středních škol ryzími institucemi střední tř́́dy; [...] tyto školy byly vskutku nástrojem určeným $\mathrm{k}$ tomu, aby $\mathrm{z}$ buržoazie vytvořily koherentní třídu [...]. Celkově lze říci, že v těchto public schools, socializace převládala nad instrukcí. (Hobsbawm 1996: 114-115) 
Maloměštáci neumějí hru kultury hrát jako hru: berou kulturu př́liš vážně na to, aby si dovolili blufovat nebo podvádět nebo, jednoduše, mít odstup a nenucenost, jež svědčí o skutečně důvěrné znalosti; berou kulturu př́liš vážně na to, aby unikli neustálé úzkosti z nevědomosti [...]. Poněvadž kulturu spojují s věděním, domnívají se, že kultivovaný člověk je ten, kdo vlastní nesmírné bohatství vědění, a nemohou uvěřit [...], že v nejjednodušším a nejsublimnějším vyjádření se kultura omezuje na vztah ke kultuře. („Kultura je to, co zůstane, když se vše zapomene.“) (Bourdieu 1979: 381)

V britském systému bylo „veřejné míněni““ inkubátorem tohoto třídního vědomí střední třídy. [...] „Jsou to příslušníci stř̌ední třídy, kteří vytvářejí množství a účinnost veřejného míněni““ - Lord Grey. (Hobsbawm 1996: 103)

Vzdělání jako prostředek budování a udržování vlastní identity; legitimní vědění, které autorizuje a je považováno za kapitál, jenž je potřeba neustále obhospodařovat; veřejné mínění, které reprezentuje existenci střední třídy vůči ní samotné a vůči celé společnosti. Možná - řekne si čtenár̆, ale jakou to má souvislost s morální normalitou? Souvislost je zde následující. Jedním ze zdrojů normality je vzdělávací systém, jehož hlavní úlohou je institucionálně kontrolovaná socializace dětí a mládeže. Spodní ani vyšší vrstvy k takovémuto vzdělání neměly commitment; pouze pro potomky př́slušníků střední vrstvy je normalizované osvojení si legitimní kultury existenční nutností. Zatímco pro nižší vrstvy je školství organizovaným disciplinačním nátlakem (především kvůli nim byla zavedena povinnost školní docházky), pro střední vrstvy je dobrovolným cvičištěm pro bitvy života: školní vzdělání je jejich distinktivním znakem.

Důležitost přikládaná vzdělání (více než náboženství) charakterizovala představu těchto středních tříd, kterou měly o sobě samých a o světě. Vzdělání (Bildung) bylo rovněž to, co umožňovalo komunikaci mezi členy těchto tříd, to, co je odlišovalo od všech těch, co s nimi nesdílely tuto formu (klasického) vzdělání. (Kocka 1996: 12)

Ovšem co se skrývá pod označením „klasické“ vzdělání, co je rezultátem tohoto vzdělání? Podle Bourdieua jsou to

dispozice, které se ukazují ve vztahu ke kultuře, taková starostlivost o konformitu, vedoucí $\mathrm{k}$ úzkostlivému hledání autorit a vzorů chování a inklinující $\mathrm{k}$ volbě jistých a potvrzených věcí (jako klasiků a literárních cen) nebo jako ve vztahu k jazyku, se sklonem $\mathrm{k}$ hyperkorektnosti [...] kde chyby v jazyce - jako jinde nesprávnost a morální chyba - nejsou jiné než ty, co se ukazují ve vztahu k morálce, s téměř neuhasitelnou žízní po technikách nebo pravidlech chování, které vedou k podřízení veškeré existence pevné disciplíně. (Bourdieu 1979: 382)

Toto vzdělání vytváří prázdnou disciplinovanost, prekurzor budoucí normality, ochotný naplnit se jakýmkoliv obsahem, jen když to bude obsah legitimní a jestliže bude nástrojem individuální i kolektivní mobility. Foucault nám podal zprávu přesně o druhu vědění

6 Tato citace se netýká střední tř́dy ve stavu zrodu, nýbrž již konstituovaného maloměštáctví. Uvádím ji zde z toho důvodu, že přesně vystihuje důležitý aspekt úlohy vědění v étosu středních vrstev. 
sloužícím cílům disciplinace - ke klasifikaci a normalizaci. Jakékoliv nesystematické a manuální vědění spodních tříd anebo neužitečné vědění tř̌íd nejvyšších do běžných škol nepatří, protože vzdoruje snaze své sociálně efektivní kapitalizace. Vyučované vědění bylo nejen nástrojem klasifikace a podmanění světa, ale především klasifikace a normalizace žáků a studentů. Žáci se učí, aby mohli být zkoušeni, rozřazeni do skupin a disciplinováni (Foucault 2000: 271). Každá z utvořených skupin pak nemá svou stavovskou morálku, nýbrž svou morální normalitu, která se může proměnit ihned po zavedení jiného druhu zkoušení a řazení.

Jednou z opor jak střední trrídy, tak morální normality, je veřejné mínění. Pro střední třídu je veřejné mínění, máme-li věřit Ericu Hobsbawmovi, inkubátorem jejího tř́ídního vědomí (Hobsbawm 1996: 103). Současně se odvažuji tvrdit, že normalita, a potažmo i morální normalita, nachází ve veřejném mínění rovněž nejlepší inkubační podmínky. Normalitu sice lze vynutit autoritativně, ovšem časem se vynucená normalita transformuje ve svého druhu morálku s odpovídajícím transcendentnem (Bohem, Stranou, Rozumem apod.). Morálka je založená na jednohlasnosti, morální normalita na mnohohlasosti. Veřejné mínění jako instituce střední třídy, oscilující mezi věděním a nevěděním, označujícím a označovaným, poskytuje nezbytný prostor pro neustálé posuzování, co je, nebo co není normální. Normalita vystupuje jako založená na empirických, nikoliv normativních, skutečnostech; vyvolává dojem souladu s realitou: např́klad to, co je přirozené, je současně normální, co se často vyskytuje, je normální. Moralita na druhé straně spojení s realitou nepředpokládá a ani ho nesimuluje: moralita platí navzdory realitě. Lhát bude nemorální, dokud bude existovat morální imperativ nelhat, nezávisle na tom, lžou-li lidé, či ne; lhát bude nenormální pouze do té doby, dokud skutečnost, že lidé lžou, neprosákne do veřejného mínění takovou měrou, že ho obrátí v prospěch lhaní.

\section{Transitivní status}

Můžeme konstatovat, že střední třídy se nacházejí v situacích obecné nestability. Všichni stoupají nebo klesají, doufají ve vzestup nebo se obávají ztroskotání. (názor z roku 1835; citováno podle Hobsbawm 1996: 107)

Asi nebude mnoho pochybností o tom, že podstatnou okolností životní situace prríslušníků středních tříd, tj. mezilehlých vrstev, byla statusová nejistota spojená s mobilitními aspiracemi (viz též Keller 2000). Členové střední vrstvy na tom byli v jistém smyslu jako duše zemřelých v očistci: každý musel usilovat o pohyb vzhůru k nebi, aby nezůstal navěky v dosahu nešt'astného podsvětí. ${ }^{7}$ Vůle jednotlivců mezilehlé vrstvy k vytrvalému pochodu nahoru vedla k určitému normativnímu oportunismu, zásadovosti jen naoko, s ochotou kdy-

Dante nám o tom v Božské komedii zanechal svědectví: „Mistr můj, i já, i ono stádce, jež bylo s ním, jsme v naslouchání stáli, neb pozornost nám poutal jako vládce. My takto jsme jen jeho tónů dbali, však hle, ctný stařec vtom nás popohání volaje: ,Dále! Zde se neotálí! Nač, duše liknavé, to prodlévání? Pospěšte $\mathrm{k}$ hoře svléci slupku hříchu, jež Boha jasně uvidět nám brání!‘“ (Božská komedie, Očistec, Zpěv druhý, verše 115-123). 
koliv přijmout zvyky vyšší vrstvy a v nouzi se uchýlit ke zvykům vrstvy nižší. Pro člověka $\mathrm{v}$ takovém postavení byla metafyzická morálka trochu na příěž, i když to neznamená, že by nebyl jejím horlivým propagátorem, zvláště jednalo-li se o ostatní, tj. nižší, př́ípadně vyšší, vrstvy.

Shrnuto, zatímco aristokraté z dobrého rodu nic neztráceli svatbou s Američankami, židovkami nebo tanečnicemi, široké vrstvy střední tř́ídy byly pronásledovány (romány té doby jsou svědectvím) strachem zadat si sňatkem s někým, kdo nebyl gentleman nebo lady. (Hobsbawm 1996: 109)

A tak pod hávem př́ísné „měšt’ácké“ morálky mohlo vypučet embryo plastické morální normality, vždy schopné se přizpůsobit aktuálním životním okolnostem.

\section{Rozšir̃ení étosu na většinu společnosti}

Tato buržoazní kultura si činila nárok na univerzalitu. Ve své odlišnosti od kultury aristokratické nebo venkovské měla spontánní sklon rozšiřit se za společenské hranice buržoazie a vtisknout svou pečet' celé společnosti. (Kocka 1996: 13)

Z dnešního ex post pohledu je tvrzení o vitalitě a expanzi střední vrstvy konstatováním dozajista silně ovlivněným současnou situací, kdy vrstvy ostatní téměř vymizely. Rovněž tak nemohu, a dokonce ani nezamýšlím, dokázat, že střední třídy „vymyslely“ normalitu, o jejímž vzniku a disciplinační moci píše tak sugestivně Foucault. Jen se domnívám, že střední třídy přijaly normalitu, a posléze i morální normalitu, jako svůj étos, staly se jeho nositelem a spolu s tím, jak se ve dvacátém století rozšiřovaly jejich řady, rozšiřoval se i tento étos. Obojí proces, strukturální i normativní, velice dobře vystihuje termín embourgeiosement. Jeho význam se neomezuje pouze na zvýšení/snížení blahobytu a na sociální možnosti s tím souvisící, ale vztahuje se i na životní postoj, lze-li to tak zvát. Luckmann s Bergerem považují za hlavní výrazy ,procesu nazývaného embourgeoisement“ deradikalizaci politiky, rozšíření rovnostářského étosu, demokratizaci v přístupu a př́ípadně i v obsahu veřejného vzdělávání, rozšiřrení konzumu podle vzoru středních trríd a masovou komunikaci, která z něj činí nutnost (Luckmann a Berger 1964: 333). Historik Kocka píše přímo o buržoazní kultuře:

„Embourgeiosement“ ostatních sociálních skupin byl jednou z podstatných složek buržoazní kultury. Školský systém, pracoviště, veřejný život a konečně sféra organizovaného volného času byly hlavní arény, ve kterých buržoazní kultura mohla rozvinout svou přitažlivou sílu, svou hegemonickou moc. Dlouhodobě nepřestala ve svém rozšiřování až $\mathrm{k}$ bodu, kdy už někdy ani nepostačovala $\mathrm{k}$ definici buržoazie. Čím více byla nějaká společnost prosáknutá buržoazní kulturou, tím těžším se stávalo identifikovat buržoazii, jak je tomu dnes v případě většiny západních zemí. (Kocka 1996: 13)

$\mathrm{Z}$ druhé strany můžeme $\mathrm{v}$ deradikalizaci politiky, rovnostářském étosu apod. vidět pronikání normality; nikoliv jako obsahu, nýbrž jako formy, kterou lze plasticky aplikovat na nejrůznější sociální situace. 


\section{Závěr}

Cílem historického expozé bylo ukázat, že ztráta pozic morálky v posledních desetiletích nemusí souviset s „morálním rozkladem“ západní společnosti ani s postmoderním ,,anything goes“, ale může mít kořeny ve zvýznamnění a překladu sociální struktury pozdně moderní společnosti do normativní oblasti. Morální normalita by tak mohla být považována za korelát masové společnosti a její textura odráží strukturu sociálních klasifikací této společnosti. Její intenzita roste a klesá spolu s tím, jak silný význam je přikládán existenci sociálního prostoru mezi vysokými a nízkými vrstvami.

Vrat'me se nyní ke třem cílům, které byly v úvodu vytyčeny. Snažil jsem se ukázat, že myslitelé, kteří zkoumali povahu současné morálky, poukazovali na potřebu transcendentálně neukotvené normativity, která by nebyla napjata v dichotomii kategorií dobra a zla, ale umožňovala by lidem žít „dobrý život“. Tuto normativní strukturu jsem identifikoval jako morální normalitu, tj. možnost, zejména diskursivní, argumentovat normalitou bez toho, aby normálnost (běžnost, relativní častost) byla ověřována. Odkaz na to, že nějaká skutečnost (jednání, osoba, jev) je normální, má totiž logickou sílu vyjmout toto jednání z morálního poměřování vzhledem k nějaké transcendentní autoritě (bůh, rozum, tradice). Na druhou stranu, posuzování morální normalitou danou skutečnost nezbavuje normativního náboje (na rozdíl od adiaforizace), ani nepředpisuje, co je užitečné nebo správné (na rozdíl od zvyklostí). Morální normalita je stále úzce napojená na sféru morálnosti a vyplňuje mezilehlý prostor mezi kategoriemi dobra a zla, jejichž význam je považován za príliš silný (patetický) na to, aby se hodily do každodenního života.

Existenci trojného vzorce charakterizujícího propojení morálky s morální normalitou jsem dokumentoval na analogické normativní představivosti pozdního středověku a zrození očistce. Podobně jako se očistec vynořil ze znovuobjevení starších klasifikací, tak i morální normalita není výrazem dnešní doby, ale transformací sociálních kategorizací staršího ražení. Konkrétně jsem poukázal na kategorii střední třídy (buržoazie) a její zkušenost, která byla převedena do určitého étosu, vyznačujícího se obavou ze špatné identifikace, důrazem na vědění a mínění a vědomím tranzitivního statusu. Tento étos, rozšířen do širokých vrstev společnosti, umožnil podle mého názoru vytvoření srozumitelné morální kategorie mezilehlé morální normality.

Výše rekapitulovanou argumentaci představuji jako pokus o kulturní sociologii, která by nerozdělovala kulturní významy a sociálně-strukturní účinky na dvě autonomní sféry příčinnosti. V durkheimovské tradici chápu kulturní klasifikace jako výrazy životní zkušenosti v určitým způsobem organizované společnosti, ale, použiji-li bourdieuovskou terminologii, tyto klasifikace jsou strukturou strukturující, to znamená, že je aktérským a strategickým způsobem používáme, abychom rozvrhovali svou budoucnost. Morální normalita je sice morální představivost, která má původ v životní zkušenosti buržoazie, ale její síla spočívá v aktuální možnosti normativní strukturace sféry, kterou nechceme podrobit silnému morálnímu napětí kategorií dobra a zla.

V článku načrtnutý obraz je zcela jistě př́liš zjednodušený a zkratkovitý, aby mohl být považován za teorii nebo úplné vysvětlení současné morálky. Šlo mi spíše o vytvoření perspektivy, ze které je možné současnou morálku zasadit do širšího sociokulturního kontextu, který by bral v úvahu jak symbolickou proměnu (ztráta významu transcendentálních autorit), 
tak proměnu sociální (masová společnost). Jsem si rovněž vědom neúplností, které můj příspěvek má, zejména nerozpracovaností konceptu normality, která zde hraje důležitou roli, ale jejíž normativní síla zůstává do značné míry nevysvětlena.

\section{Literatura}

ALEXANDER, Jeffrey. The Meanings of Social Life: A Cultural Sociology. New York: Oxford University Press, 2003. ISBN 9780198036463.

BAUDRILLARD, Jean. O svádění. Olomouc: Votobia, 1996. ISBN 8071980781.

BAUDRILLARD, Jean. Symbolic Exchange: Taking Theory Seriously. An Interview with Jean Baudrillard. Theory, Culture \& Society, 1995, roč. 12, č. 4, s. 79-95. ISSN 1460-3616.

BAUMAN, Zygmunt. Postmodern Ethics. Oxford: Blackwell, 1993. ISBN 9780631186922.

BAUMAN, Zygmunt. Úvahy o postmoderní době. Praha: Sociologické nakladatelství, 1995. ISBN 9788085850123.

BAUMAN, Zygmunt. 'Morality in the Age of Contingency'. In HEELAS, P., LASH, S. \& MORRIS, P. (eds.). Detraditionalization. Oxford: Blackwell, 1996, s. 49-58. ISBN 9781557865557.

BAUMAN, Zygmunt. Liquid Fear. Cambridge: Polity Press, 2006. ISBN 9780745636801.

BĚLOHRADSKÝ, Václav. Morální kýč. Proglas, 27. 4. 1999 [online.] ISSN 0862-6731. [cit. 21. 4. 2013]. Dostupné z: http://www.multiweb.cz/hawkmoon/strana30.htm

BOURDIEU, Pierre. La distinction: critique sociale du jugement. Paris: Éd. de Minuit, 1979. ISBN 9782707302755.

BÖHME, Gernot. Ethical Life or 'The Customary'. Thesis Eleven, 2000, roč. 60, č. 1, s. 1-10. ISSN 0725-5136.

DANTE, Alighieri. Božská komedie. Přeložil O. F. Babler. Praha: Odeon, 1989.

DURKHEIM, Emile. Pravidla sociologické metody. Praha: Orbis, 1926.

FOUCAULT, Michel. Diskurs, autor, genealogie. Praha: Svoboda, 1994. ISBN 9788020504067.

FOUCAULT, Michel. Dohližet a trestat. Kniha o zrodu vězení. Praha: Dauphin, 2000. ISBN 9788086019963.

Grand dictionnaire encyclopédique Larousse. Paris: Librairie Larousse, 1984. ISBN 9782031023104. HÁJEK, Martin. Čistota, znečištění a sociální struktura. Biograf, 2001, č. 25, s. 49-62. ISSN 1211-5770.

HÁJEK, Martin. Pojem normality v tisku a běžném hovoru - vývoj, sémantika a sociologické aspekty. In KABELE, J., POTU゚ČEK, M., PRÁZOVÁ, I. a VESELÝ, A. (eds.). Rozvoj české společnosti v Evropské unii. Praha: Matfyzpress, 2004, s. 125-134. ISBN 9788086732350.

HOBSBAWM, Eric. La Middle Class anglaise. In KOCKA, J. (ed.). Les bourgeoisies européennes au XIXe siècle. Paris: Bélin, 1996, s. 101-129. ISBN 9782701117379.

CHALUPNÝ, Emanuel. Sociologie. Díl II. svazek 2. Vývoj sociologie v 19. století (1835-1904). Praha: Samcovo knihkupectví, 1948.

KELLER, Jan. Vzestup a pád střednich vrstev. Praha: Sociologické nakladatelství, 2000. ISBN 9788085850956.

KOCKA, Jürgen. Modèle européen et cas allemand. In KOCKA, J. (ed.). Les bourgeoisies européennes au XIXe siècle. Paris: Bélin, 1996, s. 7-48. ISBN 9782701117379.

LE GOFF, Jacques. La naissance de Purgatoire. Paris: Gallimard, 1981. ISBN 9782070254101.

LE GOFF, Jacques. La bourse et la vie. Économie et religion au Moyen Age. Paris: Hachette, 1986. ISBN 9782010112126. 
LIPOVETSKY, Gilles. Soumrak povinnosti: bezbolestná etika nových demokratických časů. Praha: Prostor, 1999. ISBN 9788072600083.

LIPOVETSKY, Gilles. Hypermodern Times. 1. vyd. Cambridge: Polity Press, 2005. ISBN 9780745634210. LUCKMANN, Thomas. The Privatization of Religion and Morality. In HEELAS, P., LASH, S. a MORRIS, P. (eds.). Detraditionalization. Cambridge: Blackwell, 1996, s. 49-58. ISBN 9781557865557.

LUCKMANN, Thomas, BERGER, Peter. Social Mobility and Personal Identity. Archives europeéns de sociologie, 1964, roč. 5, s. 331-343. ISSN 1474-0583.

LYOTARD, Jean-François. Moralités postmodernes. Paris: Galilée, 1993. ISBN 9782718604305.

MARTIN, Eduard. Umění být normální. Prostor 1998, č. 37, s. 15-18. ISSN 0862-7045.

MAUSS, Marcel. Sociologie et anthropologie. Paris: Presses Universitaires de France, 1950. ISBN 9782130547181.

MAZA, Sarah. Luxury, Morality, and Social Change: Why There Was No Middle-Class Consciousness in Prerevolutionary France. The Journal of Modern History, 1997, roč. 69, č. 2, s. 199-229. ISSN 0022-2801.

MISZTAL, Barbara. Normality and trust in Goffman's theory of interaction order. Sociological Theory, 2001, roč. 19, č. 3, s. 312-324. ISSN 1467-9558.

RIESMAN, Daniel. Osamélý dav. Praha: Mladá fronta, 1968.

SCHNEEWIND, Jerome B. The invention of autonomy: a history of modern moral philosophy. Cambridge, UK: Cambridge University Press, 1998. ISBN 9780521479387.

WEBER, Max. Metodologie, sociologie a politika. Praha: OIKOMENH, 2009. ISBN 9788072983896.

WELSCH, Wolfgang. Aestheticization Processes. Phenomena, Distinctions and Prospects. Theory, Culture \& Society, 1996, roč. 13, č. 1, s. 1-24. ISSN 1460-3616.

\section{Autor}

Martin Hájek je odborným asistentem na katedře sociologie Fakulty sociálních věd UK. Zabývá se textovou analýzou a sociálními normami. Je spoluatorem knih Jak vládli? (2008, spolu s J. Kabelem) a Praktiky ne/spravedlnosti. Pojmy, slova, diskurzy. (2006, spolu s kolektivem).

Kontakt: hajek@fsv.cuni.cz 